\title{
Wangshangkia, a new Devonian ostracod genus from Dushan of Guizhou, South China
}

\author{
Junjun Song ${ }^{1,2}$ and Yiming Gong ${ }^{3}$ \\ ${ }^{1}$ CAS Key Laboratory of Economic Stratigraphy and Palaeogeography, Nanjing Institute of Geology \\ and Palaeontology, Nanjing 210008, China \\ ${ }^{2}$ Center for Excellence in Life and Paleoenvironment, Chinese Academy of Sciences, Nanjing 210008, China \\ ${ }^{3}$ State Key Laboratory of Biogeology and Environmental Geology, School of Earth Sciences, \\ China University of Geosciences, Wuhan 430074, China \\ Correspondence: Yiming Gong (ymgong@cug.edu.cn)
}

Received: 7 November 2017 - Revised: 6 February 2018 - Accepted: 14 February 2018 - Published: 27 February 2018

\begin{abstract}
Wangshangkia, a new genus of Ostracoda, from the Late Devonian in Dushan of Guizhou, South China, is described. This genus belongs to the family Bairdiocyprididae Shaver, 1961 and includes two new species, i.e. Wangshangkia dushaniensis and W. bailouiensis. The new genus is characterized by a wide ventral carina with radial striae. It is reported from the Famennian of South China and disappeared just below the Devonian-Carboniferous boundary. Wangshangkia is essentially a benthic crawler and is restricted to the shallow-marine depositional environment with a low hydrodynamic condition.
\end{abstract}

Wangshangkia: urn:lsid:zoobank.org:act:34BF01D4-D202-492D-8E27-BC508EF7EFFB

W. dushaniensis: urn:lsid:zoobank.org:act:D267C362-7510-4D19-996B-EA1848D7D025

W. bailouiensis: urn:Isid:zoobank.org:act:FE988AA0-7363-4D9E-A5AB-1526C8DBCDD9

\section{Introduction}

Late Devonian ostracods from Dushan of Guizhou, South China are highly diversified and abundant (details in Song and Gong, 2018). The new genus (Wangshangkia n. gen.) belongs to the family Bairdiocyprididae Shaver, 1961. Until now the geographical occurrence of this new genus is restricted to the Guizhou Province. Both of the new species (i.e. Wangshangkia dushaniensis n. gen., n. sp. and Wangshangkia bailouiensis n. gen., n. sp.) are recognized in shallow-water deposits of semi-restricted carbonate platform (Ma et al., 2016). The ostracod-bearing strata also yield brachiopods (Yang, 1964, 1978; Zhang et al., 2011a), corals (Zhang et al., 2011a) and conodonts (Jiang, 1994; Qie et al., 2016) in association with a rich assemblage of ostracods, as well as trace fossils (Wang and Wang, 1996; Zhang et al., 2011b). The main goals of the paper are to provide a detailed description of the new genus (Wangshangkia) and its species (W. dushaniensis and W. bailouiensis) and to discuss their palaeoecological implications.

\section{Geological setting and stratal section description}

During the late Palaeozoic, the palaeogeographic frame of South China consists of the Yangtze-Cathysia continent and the southern South China Sea. During the Late Devonian the basement of the South China block beneath the epicontinental sea was cut by various intersected rifts, developing into a complex palaeogeography of shallow-water platforms separated by deep-water basins (Dong, 1982; Ma and Bai, 2002) (Fig. 1a). The Baihupo section (N 2550'14.14", E $\left.107^{\circ} 30^{\prime} 26.56^{\prime \prime}\right)$ is located along the road from Bailou Village (Dushan County) to Feifengjing Village (Dushan County), about $3 \mathrm{~km}$ southwest of Dushan City, Guizhou (Fig. 1a). It crops out along the west limb of the Dushan anticline and displays the most complete Devonian-Carboniferous (D-C) transitional beds. Biostratigraphy and sedimentology have been studied in detail at the Baihupo section (Wang and Wang, 1996; Wang, 2001; Zhang et al., 2011a, b). The studied section shows a continuous sedimentary succession from the Late Devonian to early Carboniferous with the Zhe- 
(a)
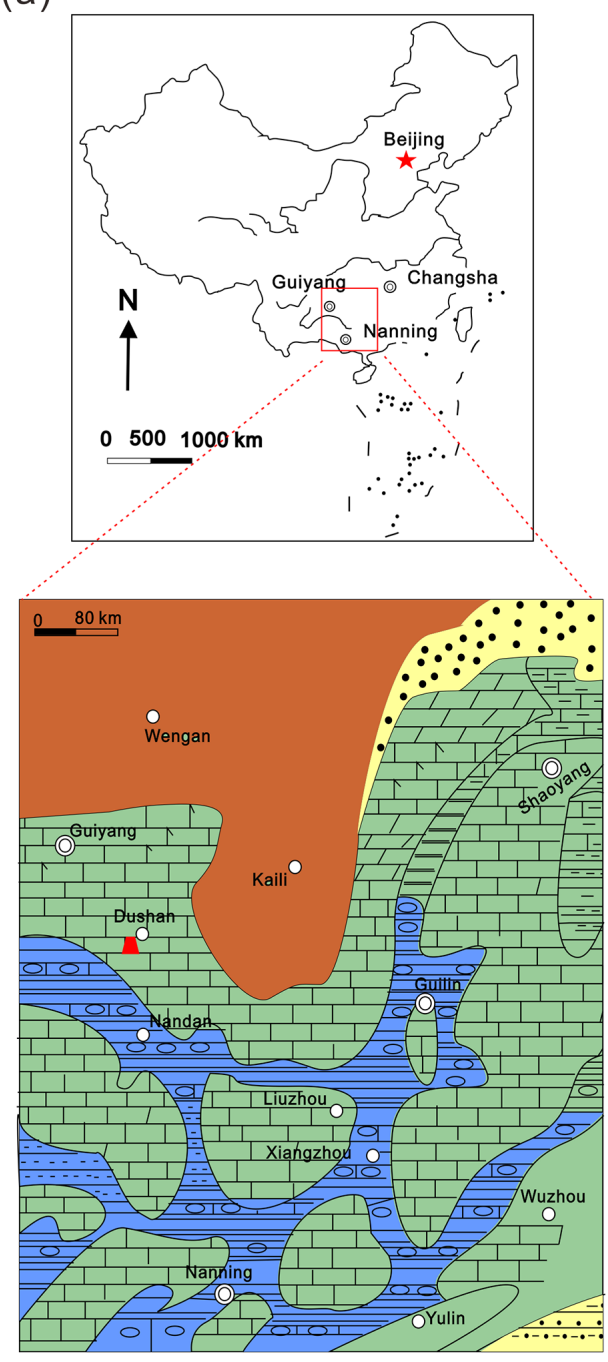

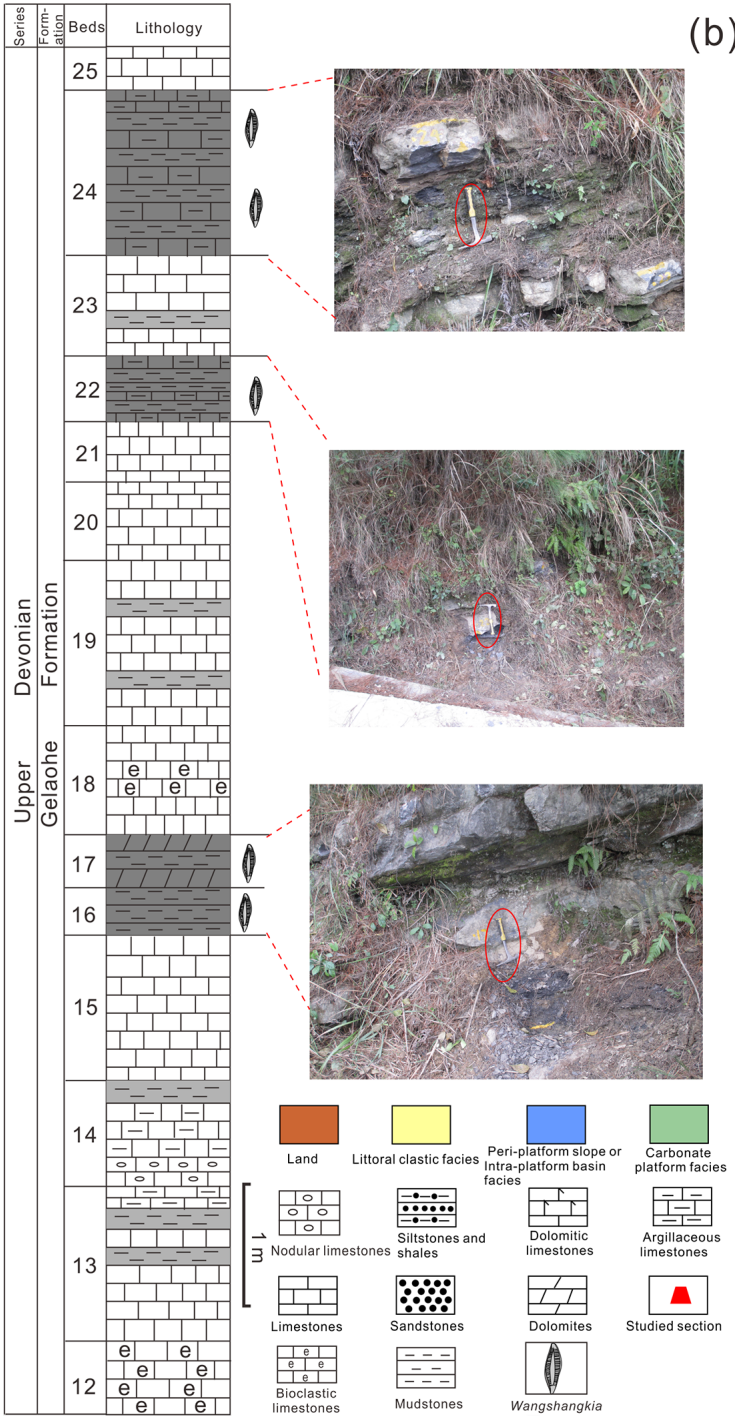

(b)

Figure 1. (a) Late Devonian lithofacies and palaeogeography of South China (modified after Ma et al., 2016) with the location of the studied section. (b) Late Devonian sequence and field photographs in the Dushan area (Guizhou, China), showing the stratigraphic position of Wangshangkia $\mathrm{n}$. gen.

wang, Gelaohe and Tangbagou formations in ascending order. Among them, the Gelaohe Formation ( $58.5 \mathrm{~m}$ thick), which is dated to the Famennian (Zhang et al., 2011a), can be divided into three parts. The lower part (Beds 1-7) is composed of grey to dark grey thick-bedded bioclastic limestones intercalated with thin-bedded shales and mudstones; the middle part (Beds 8-20) is about $27 \mathrm{~m}$ thick and is characterized by dark grey thin-bedded shales interbedded with wackstones and bioclastic limestones; the upper part (Beds 21-28) is about $15.6 \mathrm{~m}$ thick consisting of dark grey thinbedded argillaceous limestones intercalated with mudstones. The stratigraphic range of Wangshangkia is limited to the Gelaohe Formation (mainly in the Beds 16-24) (Fig. 1b).

\section{Materials and methods}

A total of 30 samples were collected from the Zhewang and Gelaohe formations in the Baihupo section and each sample weighted about $1000 \mathrm{~g}$. The methodology, known as "hotacetolysis", was used to extract ostracods from limestones (Lethiers and Crasquin-Soleau, 1988; Crasquin-Soleau et al., 2005). About 3000 specimens were obtained from the Baihupo section, contributing to 37 species belonging to 25 genera (Song and Gong, 2018). Among them, the new genus is represented by about 85 specimens including single valves and carapaces from five samples (Fig. 1b). All specimens shown in this paper are deposited in the palaeontological collections of the museum of the China University of Geosciences (Wuhan) (collection DSBL2014). 

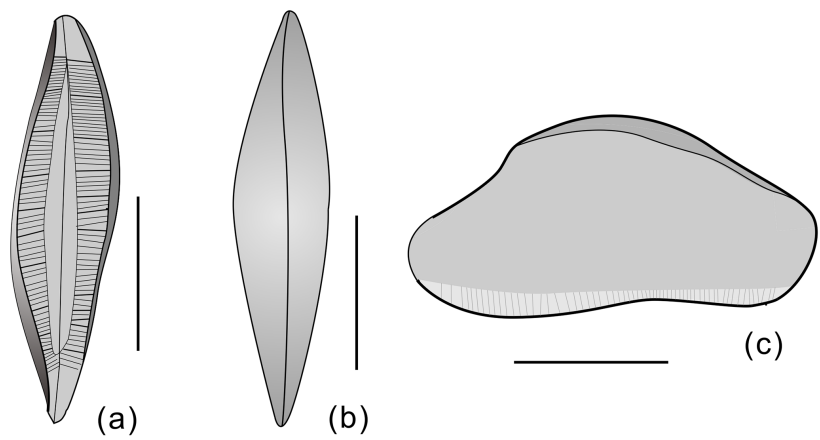

(b)

Figure 2. Interpretative drawing of the ventral view (a), dorsal view (b) and right lateral view (c) of the holotype of Wangshangkia dushaniensis. All scale bars represent $500 \mu \mathrm{m}$.

\section{Systematic palaeontology}

Abbreviations: $\mathrm{AB}$, anterior border; $\mathrm{PB}$, posterior border; $\mathrm{DB}$, dorsal border; $\mathrm{ADB}$, anterodorsal border; $\mathrm{VB}$, ventral border; $L$, maximum length; $H$, maximum height; $W$, maximum width.

\section{Class Ostracoda Latreille, 1806}

Order Podocopida Sars, 1866

Superfamily Bairdiocypridoidea Shaver, 1961

Family Bairdiocyprididae Shaver, 1961

Genus Wangshangkia $\mathrm{n}$. gen.

Type species: Wangshangkia dushaniensis $\mathrm{n}$. sp.

Other species: Wangshangkia bailouiensis n. sp.

Diagnosis: Large Bairdiocyprididae convex-backed in lateral outline. Left valve distinctly larger than right valve. Ventral carina developed with radial striae. Wide contact surface at ventral view.

Etymology: In honour of Professor Wang Shangqi from the Nanjing Institute of Geology and Palaeontology, Chinese Academy of Sciences, who made a contribution to Palaeozoic ostracod study of South China.

Occurrence: Known only from the Gelaohe Formation (Late Devonian) exposed in the Baihupo section in Dushan, Guizhou, South China.

Remarks: Wangshangkia $\mathrm{n}$. gen. has some resemblance to Xixionopsis Becker and Sanchez de Posada, 1977, but the new genus is distinguished from Xixionopsis by the wide ventral carina with radial striae, and without spines or flanges anteriorly.

Wangshangkia dushaniensis $\mathrm{n} . \mathrm{sp}$.

(Figs. 2, 3)

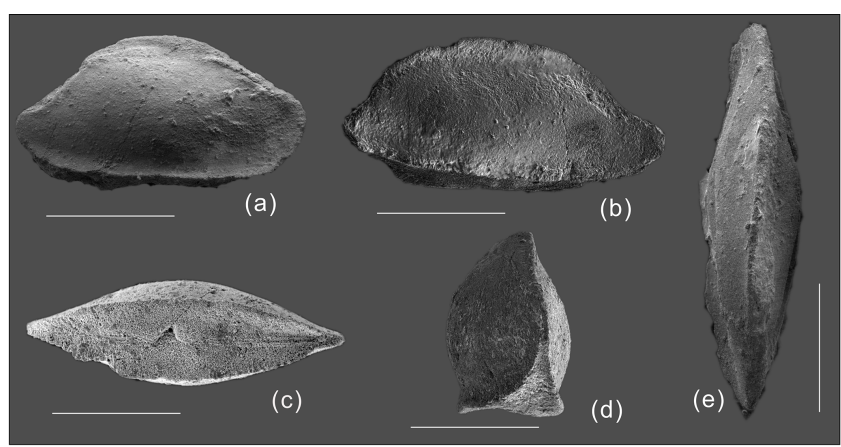

Figure 3. Wangshangkia dushaniensis n. gen., n. sp. (a) Holotype, right lateral view of complete carapace; DSBL2014001. (b) Paratype, left lateral view of complete carapace; DSBL2014002. (c) Paratype, ventral view of complete carapace; DSBL2014003. (d, e) Paratype, anterior and dorsal views of complete carapace, respectively; DSBL2014004. All scale bars represent $500 \mu \mathrm{m}$.

Holotype: One complete carapace (Figs. 2, 3a), DSBL2014001.

Diagnosis: The same as the genus.

Occurrence: Known only from the Gelaohe Formation (Late Devonian) exposed in the Baihupo section in Dushan, Guizhou, South China.

Description: Large and convex-backed in lateral outline. $\mathrm{DB}$ regularly convex. $\mathrm{AB}$ with relatively large radius of curvature with maximum located a little below mid- $H$; PB with small radius of curvature with maximum located at lower third of $H$, a little tapering; VB slightly curved. Wide ventral carina developed with radial striae. Left valve overlaps the right one with maximum at DB and ADB. Wide contact surface at ventral view. Surface smooth.

Etymology: From the locality Dushan County.

Other material: Three paratypes (Fig. 3b-e): DSBL2014002, DSBL2014003 and DSBL2014004. Other specimens: 12 complete carapaces and 15 valves, DSBL2014010-036.

Dimensions: Holotype: $L=1.1 \mathrm{~mm}, \quad H=0.60 \mathrm{~mm}$, $W=0.36 \mathrm{~mm}$; paratypes: $L=1.06-1.48 \mathrm{~mm}, H=0.58$ $0.80 \mathrm{~mm}, W=0.35-0.40 \mathrm{~mm}$.

Remarks: Wangshangkia dushaniensis n. gen., n. sp. resembles Xixionopsis subtrapezoidalis (Wang and Shi, 1982) from the Middle Devonian of Guangxi, South China, in the outline, but differs from it by the ventral carina with radial striae and shorter DB. 


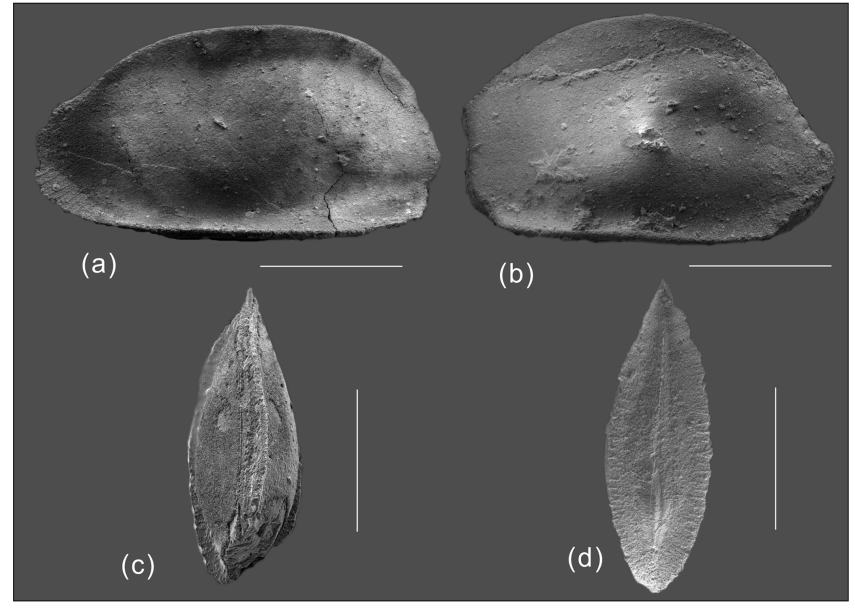

Figure 4. Wangshangkia bailouiensis n. gen., n. sp. (a) Holotype, right lateral view of complete carapace; DSBL2014006. (b) Paratype, left lateral view of complete carapace; DSBL2014007. (c) Paratype, dorsal view of complete carapace; DSBL2014008. (d) Paratype, ventral view of complete carapace; DSBL2014009. All scale bars represent $500 \mu \mathrm{m}$.

\section{Wangshangkia bailouiensis $\mathrm{n}$. sp.}

(Fig. 4)

Holotype: One complete carapace (Fig. 4a), DSBL2014006.

Diagnosis: A species of Wangshangkia with long and convex DB and straight VB.

Occurrence: Known only from the Gelaohe Formation (Late Devonian) exposed in the Baihupo section in Dushan, Guizhou, South China.

Description: Carapace large and relatively elongate in lateral view. $\mathrm{DB}$ long and regularly convex. $\mathrm{AB}$ with relatively large radius of curvature with maximum located at mid- $H$; PB with large radius of curvature with maximum located a little below mid- $H$, and radial striae exited along PB in some specimens; VB nearly straight with wide carina. Left valve slightly overlaps the right one with maximum at DB. Wide contact surface at ventral view. Surface smooth.

Etymology: After the locality, Bailou Village.

Other material: Three paratypes (Fig. 4b-d): DSBL2014007, DSBL2014008 and DSBL2014009. Other specimens include eight complete carapaces and 10 valves, DSBL2014037-054.

Dimensions: Holotype: $L=1.42 \mathrm{~mm}, \quad H=0.70 \mathrm{~mm}$, $W=0.60 \mathrm{~mm}$; paratypes: $L=1.01-1.42 \mathrm{~mm}, H=0.40$ $0.71 \mathrm{~mm}, W=0.40-0.58 \mathrm{~mm}$.
Remarks: Wangshangkia bailouiensis n. gen., n. sp. is different from Wangshangkia dushaniensis by its longer DB and straighter VB, and less overlap on DB.

\section{Discussion}

Originally, Bairdiocyprididae was described as follows: convex-backed ostracods of bythocypridid shapes, mostly without ornamentation and sculpturing left valve larger, with overlap and overreach of left valve over right valve; lacking separated calcified inner lamella but with short hinges and contact margins simply ridged and grooved in platycopine fashion (Moore, 1961).

However, the modern view (see Becker, 2000) did not support the original view that "Bairdiocyprididae are intermediate morphologically between Healdiidae and Bairdiidae". Bairdiocyprididae was characterized by "subtriangular carapace outlines, hinge-line straight or lightly arched, not significantly depressed; hinge tripartite or undivided, apical region high to low; bow-shaped projection mostly distinct, stop ridges in the larger valve". Wangshangkia n. gen. meets the main characteristics (e.g. shape, overlap and hinge structures) of Bairdiocyprididae. However, it is a little confused that both new species own a wide ventral carina with radial striae, which is rarely detected in the family of Bairdiocyprididae. Bairdiocypridids like Bairdiocypris, Baschkirina, Praepilatina and Xixionopsis are known to be typical Devonian genera, which also range up to the Carboniferous (Moore, 1961; Becker, 2000). Most of the species of the four mentioned genera are reported from worldwide Devonian deposits. So far Wangshangkia is only reported in the Famennian of South China. Moreover, the new genus may sensitively respond to the $\mathrm{D}-\mathrm{C}$ event, which is emphasized to be one of the most severe bio-events in the Phanerozoic (Walliser, 1996) because both of the two new species disappeared just below the Devonian-Carboniferous boundary in the study section.

Morphologically, Wangshangkia $\mathrm{n}$. gen. is characterized by the middle-large size (the length is more than $0.90 \mathrm{~mm}$; Becker, 1971), thin dorsal border and thick ventral border with a low centroid, which suggest a benthic crawler. The well-developed ventral carina and some forms of marginal structures might prevent the shell from sinking into the soft ground during the benthic crawling (Wang, 1988). In the field, the new-species-bearing strata are dark thin-bedded shales or wackstones, implying a low energy with abundant organic matter (Wang and Wang, 1996). The trace fossils from the Gelaohe Formation also suggest the shallow-marine low-energy environment (Wang and Wang, 1996; Zhang et al., 2011b). As we know, most of the species of Bairdiocypridoidea are considered to be deposit feeders for their well-developed muscle scars (Adamczak, 1969; Lethiers and 
Whatley, 1994). In summary, we suggest that Wangshangkia n. gen. is essentially a benthic crawler and deposit feeder living in the shallow-marine, low-energy waters with abundant food supply.

\section{Conclusions}

Wangshangkia n. gen. from the Late Devonian of Dushan, Guizhou, South China, represents a new member of the family Bairdiocyprididae Shaver, 1961 with distinct radial striae on the wide ventral carina. Two new species belonging to Wangshangkia, i.e. W. dushaniensis and W. bailouiensis, are recognized. The morphological features of the new genus indicate that it is essentially a benthic crawler living in the shallow-marine low-energy waters with abundant food supply. The new genus is so far only reported in the Famennian of South China, which disappeared just below the DevonianCarboniferous boundary.

Data availability. No data sets were used in this article.

Competing interests. The authors declare that they have no conflict of interest.

Acknowledgements. We thank Sylvie Crasquin (Université Pierre et Marie Curie, France) and Jean-Georges Casier (RBINS, Brussels, Belgium) for helpful discussions. We gratefully acknowledge Ruoying Fan, Xinsong Zhang, Junning Su and Zhenzhong Xiang for their joint fieldwork. We thank Caohui Dong for his assistance in the field and laboratory work. This study was financially supported by the Natural Science Foundation of China (grant nos. 41290260, 41472001).

Edited by: Thomas M. Cronin

Reviewed by: Jean-Georges Casier and one anonymous referee

\section{References}

Adamczak, F.: On the question of whether the palaeocope ostracods were filter-feeders, in: The taxonomy, morphology and ecology of recent ostracoda, edited by: Neale, J., Oliver and Boyd, Edinburgh, 93-98, 1969.

Becker, G.: Paleoecology of Middle Devonian ostracods from Eifel region, Germany: Paléoécologie des Ostracodes, Bulletin du Centre Recherches Pau-SNPA, 5 (suppl.), 801-816, 1971.

Becker, G.: Contributions to Palaeozoic Ostracod Classification [POC], No.16. The Superfamily Bairdiocypridacea Shaver, 1961-4. Family Bairdiocyprididae Shaver, 1961, Neues Jahrbuch für Geologie und Neues Paläontologie, Mh., 5, 271-286, 2000.
Becker, G. and Sanchez de Posada, L. C.: Ostracoda from the Moniello Formation of Asturias (Devonian; N. Spain), Palaeontographica Abt. A, 158, 115-203, 1977.

Crasquin-Soleau, S., Vaslet, D., and Le Nindre, Y. M.: Ostracods as markers of the Permian/Triassic boundary in the Khuff Formation of Saudi Arabia, Palaeontology, 48, 853-868, 2005.

Dong, R. S.: Geotectonic Evolution and Devonian Palaeotectonic Framework in South China, Journal of Chengdu College of Geology, 19, 58-64, 1982 (in Chinese with English abstract).

Jiang, J. J.: The Devonian-Carboniferous boundary based on Lower Carboniferous conodonts in Guizhou, Regional Geology of China, 1, 21-27, 1994 (in Chinese with English abstract).

Lethiers, F. and Crasquin-Soleau, S.: Comment extraire des microfossiles à tests calcitiques de roches calcaires dures, Revue de Micropaléontologie, 31, 56-61, 1988.

Lethiers, F. and Whatley, R.: The use of Ostracoda to reconstruct the oxygen levels of Late Palaeozoic oceans, Mar. Micropaleontol., 24, 57-69, 1994.

Ma, X. P. and Bai, S. L.: Biological, depositional, microspherule, and geochemical records of the Frasnian / Famennian boundary beds, South China, Palaeogeogr. Palaeocl., 181, 325-346, 2002.

Ma, X. P., Gong, Y. M., Chen, D. Z., Racki, G., Chen, X. Q., and Liao, W. H.: The Late Devonian Frasnian-Famennian Event in South China - Patterns and causes of extinctions, sea level changes, and isotope variations, Palaeogeogr. Palaeocl., 448, 224-244, 2016.

Moore, R. C.: Treatise on invertebrate paleontology, pt. Q, Arthropoda 3-Crustacea Ostracoda, Geological Society of America and University of Kansas Press, Kansas, 465 pp., 1961.

Qie, W. K., Wang, X. D., Zhang, X. H., Ji, W. T., Grossman, E. L., Huang, X., Liu, J. S., and Luo, G. M.: Latest Devonian to earliest Carboniferous conodont and carbon isotope stratigraphy of a shallow-water sequence in South China, Geol. J., 51, 915935, 2016.

Song, J. J. and Gong, Y. M.: Ostracods from the DevonianCarboniferous transition in Dushan of Guizhou, South China, Palaeobio. Palaeoenv., in press, 2018.

Walliser, O. H.: Global events in the Devonian and Carboniferous, in: Global Events and Event Stratigraphy in the Phanerozoic, edited by: Walliser, O. H., Springer-Verlag, Berlin, 225250, 1996.

Wang, S. Q.: Late Paleozoic ostracode associations from South China and their paleoecological significance, Acta Palaeontologica Sinica, 27, 91-102, 1988 (in Chinese with English abstract).

Wang, S. Q. and Shi, C. G.: Middle Devonian ostracoda from Xiangzhou and Wuxuan Districts of Guangxi, Memoir of Nanjing Institute of Geology \& Palaeontology Academy Sinica, 5, 83154, 1982 (in Chinese with English abstract).

Wang, Y.: On outcrop Sequence Stratigraphy of Carboniferous in Dushan, Guizhou, Guizhou Geology, 18, 217-223, 2001 (in Chinese with English abstract).

Wang, Y. and Wang, X. L.: Trace fossils near DevonianCarboniferous Boundary section in Dushan, Guizhou, Journal of Stratigraphy, 20, 285-290, 1996 (in Chinese with English abstract).

Yang, S. P.: Lower Carboniferous Tournaisian Brachiopods from Southeast of Guizhou, Acta Palaeontologica Sinica, 12, 82-116, 1964 (in Chinese). 
Yang, S. P.: Lower Carboniferous Brachiopod fauna and its Stratigraphic Significance in Guizhou, Memoir of Nanjing Institute of Geology \& Palaeontology Academy Sinica, 5, 78-142, 1978 (in Chinese).

Zhang, L. J., Gong, Y. M., and Ma, H. Z.: The Devonian trace fossils and ichnofacies from South China, Journal of Palaeogeography, 13, 397-318, 2011 b (in Chinese with English abstract).
Zhang, Y. B., Sun, Y. L., and Ma, X. P.: Comprehensive biostratigraphic study of the Devonian-Carboniferous boundary in the shallow marine facies of Dushan, Guizhou., Memoir of the 26th National Congress of the Palaeontological Society of China, 8586, 2011a (in Chinese). 